\title{
WestVirginiaUniversity
}

THE RESEARCH REPOSITORY @ WVU

West Virginia Agricultural and Forestry Experiment

Davis College of Agriculture, Natural Resources

Station Bulletins

And Design

$1-1-1969$

\section{Influence of selected variables on certain beef carcass traits}

James Leonard McBee

David H. Bowers

Follow this and additional works at: https://researchrepository.wvu.edu/ wv_agricultural_and_forestry_experiment_station_bulletins

\section{Digital Commons Citation}

McBee, James Leonard and Bowers, David H., "Influence of selected variables on certain beef carcass traits" (1969). West Virginia Agricultural and Forestry Experiment Station Bulletins. 575T.

https://researchrepository.wvu.edu/wv_agricultural_and_forestry_experiment_station_bulletins/683 @ WVU. It has been accepted for inclusion in West Virginia Agricultural and Forestry Experiment Station Bulletins by an authorized administrator of

The Research Repository @WVU. For more information, please contact ian.harmon@mail.wvu.edu. 
West Virginia University Libraries 


\section{Digitized by the Internet Archive in 2010 with funding from \\ Lyrasis Members and Sloan Foundation}




\section{INFLUENCE OF SELECTED VARIABLES}

\section{ON CERTAIN BEEF CARCASS TRAITS}
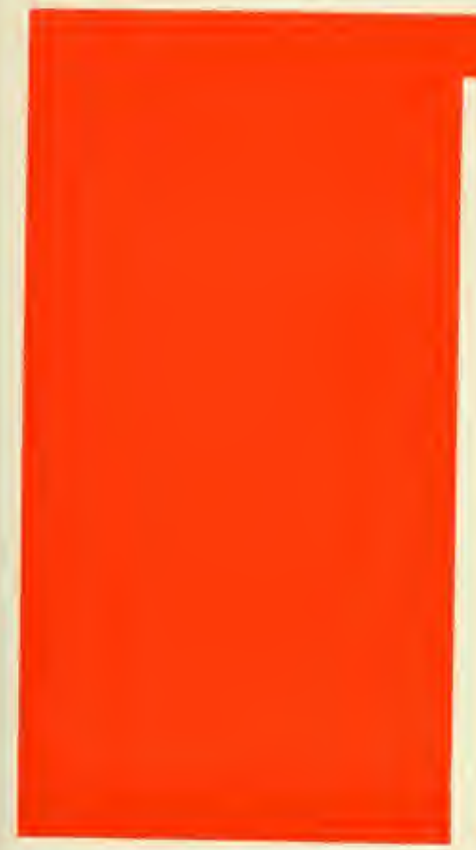

West Virginia University Agricultural Experiment Station Bulletin 575T

March 1969 


\section{THE AUTHORS}

James L. McBee, Jr. is Associate Animal Husbandman; David H. Bowers was a Graduate Research Assistant at the time of this study.

West Virginia University

Agricultural Fxperiatent Station

College of Agriculture and Forestre

A. H. VanLandingham, Director

MoRgaNTOWN 


\section{Influence of Selected Variables On Certain Beef Carcass Traits}

JAMES L. MCBEE, JR, and DAVID H. BOWERS

\section{Introduction}

7 HE VALUE of a beef carcass is determined primarily by the relative proportions of muscle, fat and bone, by the distribution of these components and the acceptability of the saleable portions. Carcass measurements have been used, with varying legrees of success, to estimate these proportions and therefore the value of the carcass. Other methods, such as dissection and chemical analysis of the complete carcass, are extremely expensive.

Neat packers and retailers desire a beef carcass which has a high ratio of lean to fat and satisfactory eating quality. Two of the most frequently used objective carcass measurements to predict the lean:fat ratio are longissimus dorsi muscle area and subcutaneous fat thickness at the 12-13th rib. These measurements are also used in the U.S.D.A. Yield Grading System. It is probable these commonly used objective measurements are related to or influenced by other relatively easy-toobtain measurements which could be incorporated into prediction equations to estimate desirable carcass traits.

The purpose of this study was to determine the relationships between carcass weight, carcass grade, fat thickness and length, width and area of the longissimus dorsi muscle. Regression equations using the above carcass traits were formulated to estimate rib eye area.

\section{Literature Review}

Several objective carcass measurements have been employed to predict the proportion of lean meat in the carcass. Hirzel (1939) ntilized maximum width times maximum length of the rib eye as a measure of muscle area. Naumann (1951) recommended a procedure for measuring longissimus dorsi area, tracing the outline of the muscle cross-section at the 12 th rib. The tracing was made on non-absorbent paper, subscquenty measured with a compensating planimeter and expressed in square inches. 
Weslie et al. (1958) reported 10 to 18 per cent of the variation in separable lean of the carcass was associated with longissimus dorsi area. Longissimus dorsi area accounted for 19 to 23 per cent of the variation in weight of trimmed wholesale cuts and weight of trimmed primal cuts according to Hedrick et al. (1963). Cole et al. (1962) reported simple correlations of $0.58,0.59,0.39$ and 0.63 between total separable lean and longissimus dorsi area at the 5 th rib, 12 th rib, last lumbar vertebra and an average of the three area measurements, respectively. In a study by Cahill et al. (1956) a correlation of 0.85 was reported between longissimus dorsi area and per cent edible portion of the carcass.

Miller et al. (1965) noted that longissimus dorsi muscle area increased approximately 0.5 times from the lightest weight group (mean $=377$ lbs.) to the heaviest weight group (mean $=878$ lbs.), whereas fat thickness increased three times. Longissimus dorsi muscle measurements were more highly associated with weight than with per cent retail cuts. These workers found that subcutaneous fat thickness measurements were associated with two or three times as much of the variation in retail yield as was longissimus dorsi muscle area, and that per cent total fat trim influenced retail yield more than any other variable studied.

Merkel and Mackintosh (1961) found a correlation of -0.91 between total lean and total fat of the beef carcass. Wiles (1966) computed significant correlations of $0.21,0.19,0.14$ and 0.23 between carcass weight and fat thickness over the rib eye and length, width and area of the longissimus dorsi muscle, respectively. Carcass grade was significantly correlated with carcass weight $(0.88)$ and fat thickness over the rib eye $(0.23)$, but not with longissimus dorsi muscle length, width or area. Longissimus dorsi muscle length was significantly correlated with width $(0.33)$ and area $(0.69)$, and width was significantly correlated with area (0.62) .

\section{Experimental Procedure}

Carcasses from 1,672 steers were used in this experiment. Data collected included carcass weight, carcass grade, subcutaneous fat thickness and rib eye length, width and area. These cattle were slaughtered at three packing plants, with ribbing being done by various plant personnel. Carcasses ranged in weight from 210 to 937 pounds. Carcasses graded Prime, Choice, Good and Standard, and were numerically coded for statistical purposes with $\mathrm{l}$ equivalent to Prime and 4 equivalent tc Standard. Fat thickness over the rib eye and rib eye length, width and area were determined according to the methods outlined by Wile: (1966) . 
The datat were partitioned into the lollowing weight groups:

(1) below 349 pounds

(2) 350 to 399 pounds

(3) 400 to 449 pounds

(4) 450 to 499 pounds

(5) 500 to 549 pounds

(6) 550 to 599 pounds
(7) 600 to 649 pounds

(8) 650 to 699 pounds

(9) 700 to 749 pounds

(10) 750 to 799 pounds

(11) 800 to 849 pounds

(12) over 850 pounds

Simple correlation coclficients were calculated for carcass grade, carcass weight, carcass weight squared, lat thickness over the rib eye, rib eye length $x$ width and rib eye length, width and area within each weight group.

Three weight groups were mate by pooling groups 1 through 4, 5 through 9, and 10 through 12. A multiple linear regression analysis was used to obtain regression coefficients for the carcass trats involved in this study. Simple correlation coefficients were calculated between the above mentioned carcass traits.

The data from all weight groups were pooled to calculate regression coefficients and simple correlation coefficients for the carcass traits.

\section{Results and Discussion}

The average carcass grade, average carcass weight, carcass weight squared, external fat thickness, external fat thickness per 100 pounds carcass weight, rib eye length, rib eye width, rib eye width $\mathrm{x}$ length, rib eye area and rib eye area per 100 pounds carcass weight of 1,672 steer rarcasses by 50 -pound weight groups, pooled into three weight groups and pooled into a single weight group, are presented in Table 1. Within the 50-pound weight groups, external fat thickness, rib cye length, rib eye width, rib eye width $\mathrm{x}$ length and rib eye area consistently increased with each increase in carcass weight. Rib eye area increased :pproximately two times from the lightest to heaviest weight group, while fat thickness increased approximately six times. The lighter reight carcasses had greater rib eye areas per 100 pounds carcass weight than the heavier carcasses. External fat thickness per 100 pounds carcass weight was essentially the same for all weight groups except the extremely light-weight carcasses. Carcass grade was consistently higher with each increase in carcass weight, with minor variations in the upper weight ranges.

When the data were pooled into three weight ranges, consistent increases in all variables were observed for each increase in carcass weight.

Simple correlation coeflicients within the 50-pound weight groups are presented in Table 2. Simple correlation coefficients for the data 


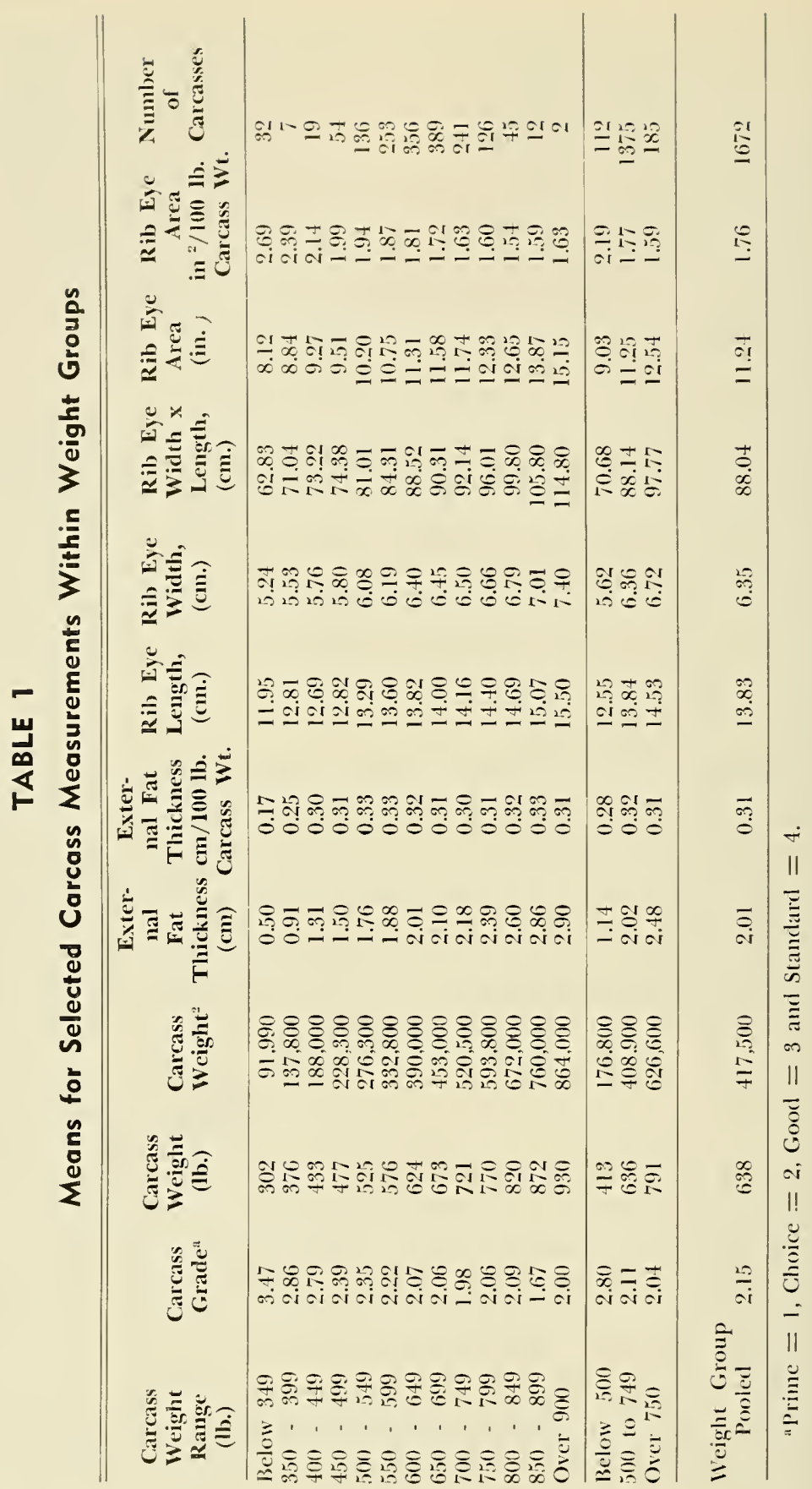


when pooled into three weight groups and into a single weight group, respectively, are shown in Table 8 and 4.

Correlation coefficients between carcass grade and carcass weight, carcass weight and fat thickness indicate these characteristics are positively related to the fartors determining carcass grade (conformation, marbling and maturity) for carcasses weighing less than 500 pounds. Carcass weight, carcass weight ${ }^{2}$ and fat thickness were not as closely related to these grade factors in heavier carcasses. Marbling was highly correlated with fat thickness and higher conformation scores were associated with heavier carcasses. Variability in fat thickness measurements and carcass weight apparently were too large to show a higher relationship in heavier carcasses.

The relationship between carcass grade and rib eye measurements declined as carcass weight increased from the light-weight group to the heavy-weight group. Variability in rib eye measurements and carcass grade apparently increased as carcass weight increased.

Carcass weight and carcass weight ${ }^{2}$ were more closely related to rib eye measurements in carcasses weighing below 500 pounds than over 500 pounds. These results indicate muscling affected carcass weight more than dicl fat in the lighter carcasses.

External fat thickness was highly correlated with carcass grade, weight and weight ${ }^{2}$ for carcasses weighing below 500 pounds. Correlations between fat thickness and rib eye area were positive for carcasses weighing less than 500 pounds, negative for carcasses weighing 500 to 750 pounds and negative for carcasses weighing over 750 pounds. When the correlations between fat thickness and rib eye area were compared within the 50-pound weight groups, all of the coefficients were negative.

Correlations between fat thickness and rib eye width indicated fat deposition increased as rib eye width increased at lighter weights. For carcasses weighing over 500 pounds, correlations indicated fatter carcasses had smaller eye measurements. Rib eye width was more highly correlated with rib eye length $x$ width and with rib eye area than was rib eye length in some weight groups, and the opposite was true in other weight groups.

A small, but significant relationship was observed between rib eye length and rib eye width for all weight groups. Rib eye length was highly correlated with rib eye length $x$ width and rib eye area. The high correlation coefficients between rib eye length $\mathrm{x}$ width and rib eye area were expected.

Multiple correlation coefficients between rib cye area and selected carcass measurements and equations for predicting rib eye area of carcasses falling within specified weight ranges are presented in Table 5. 


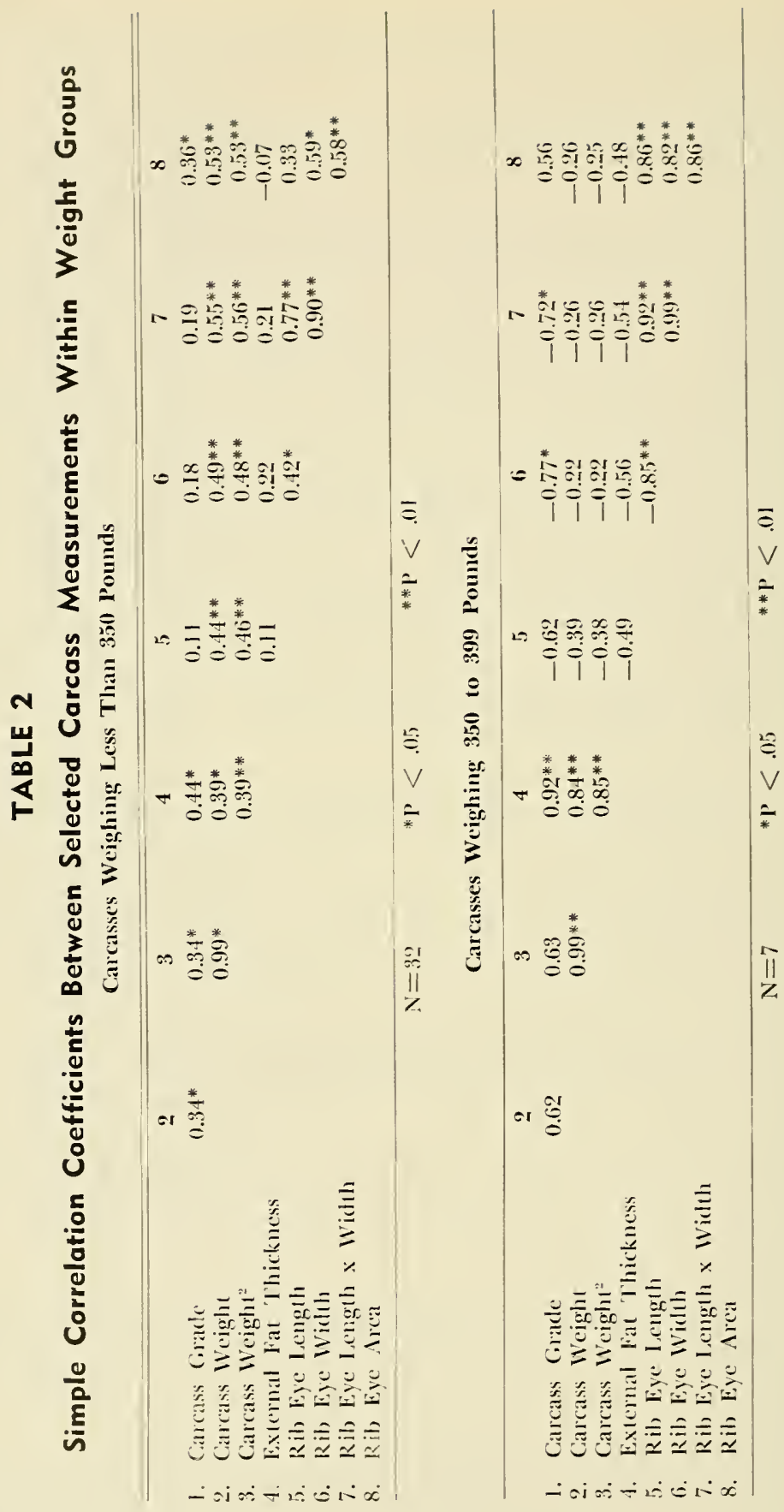




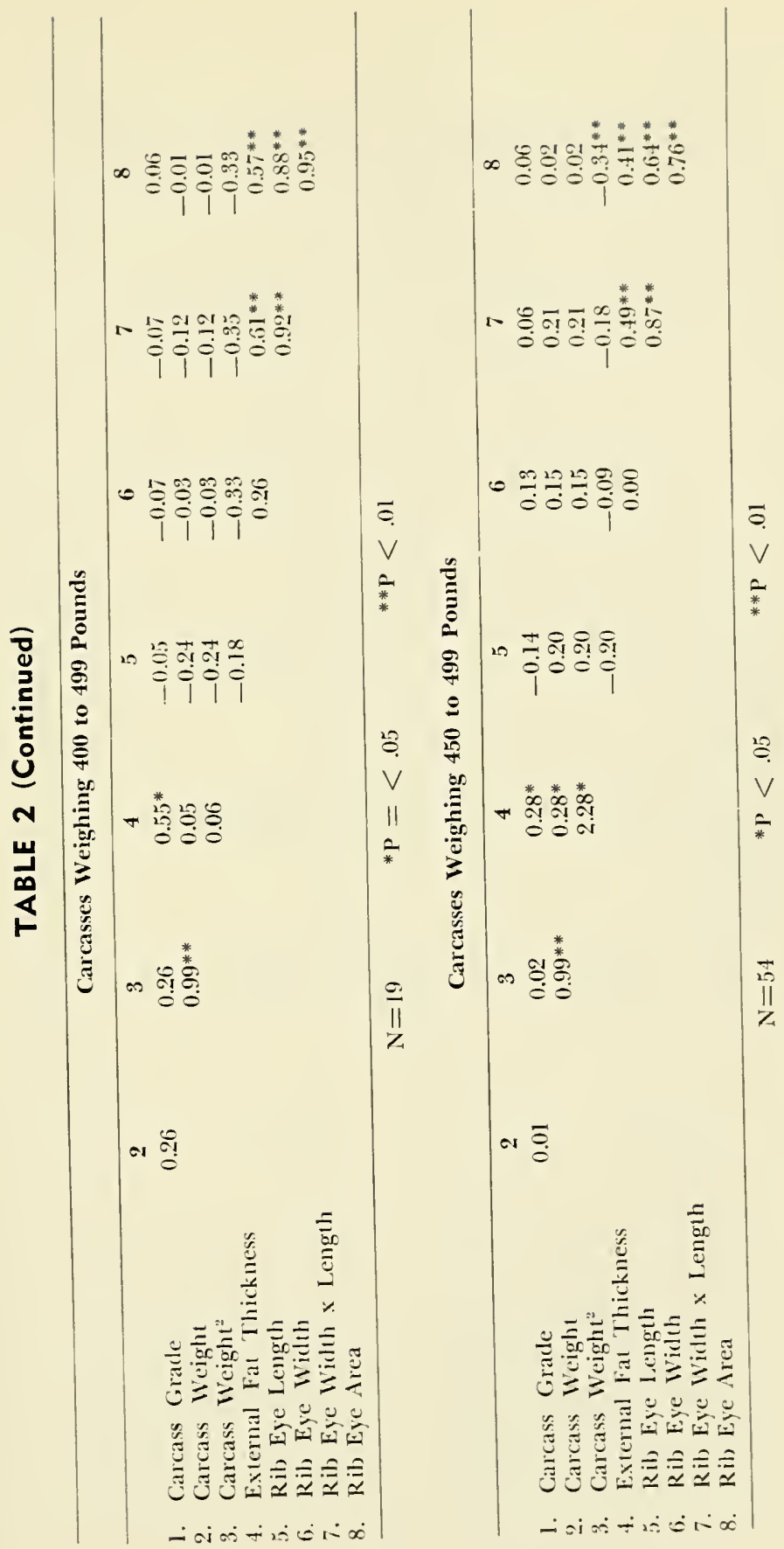




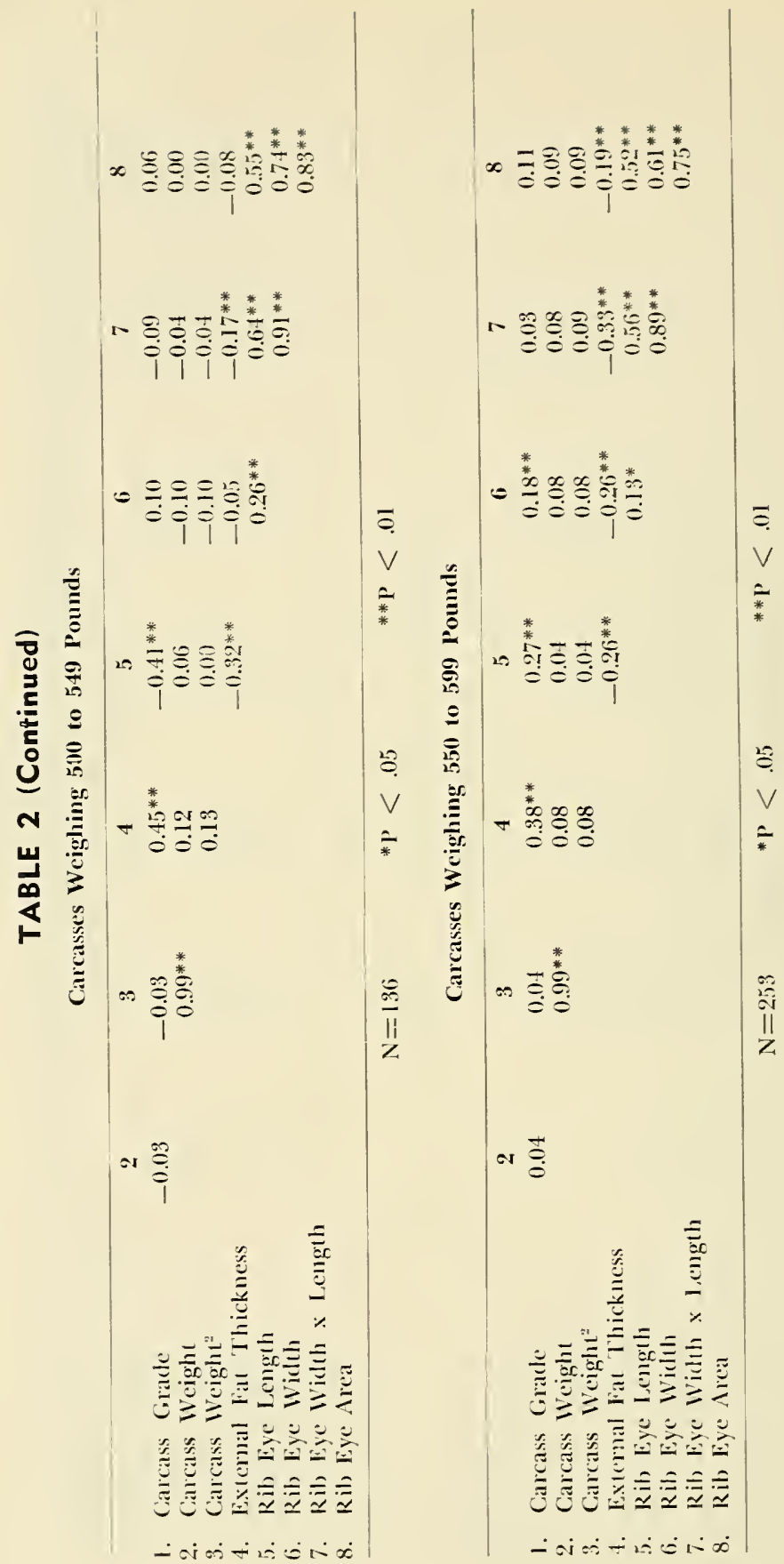




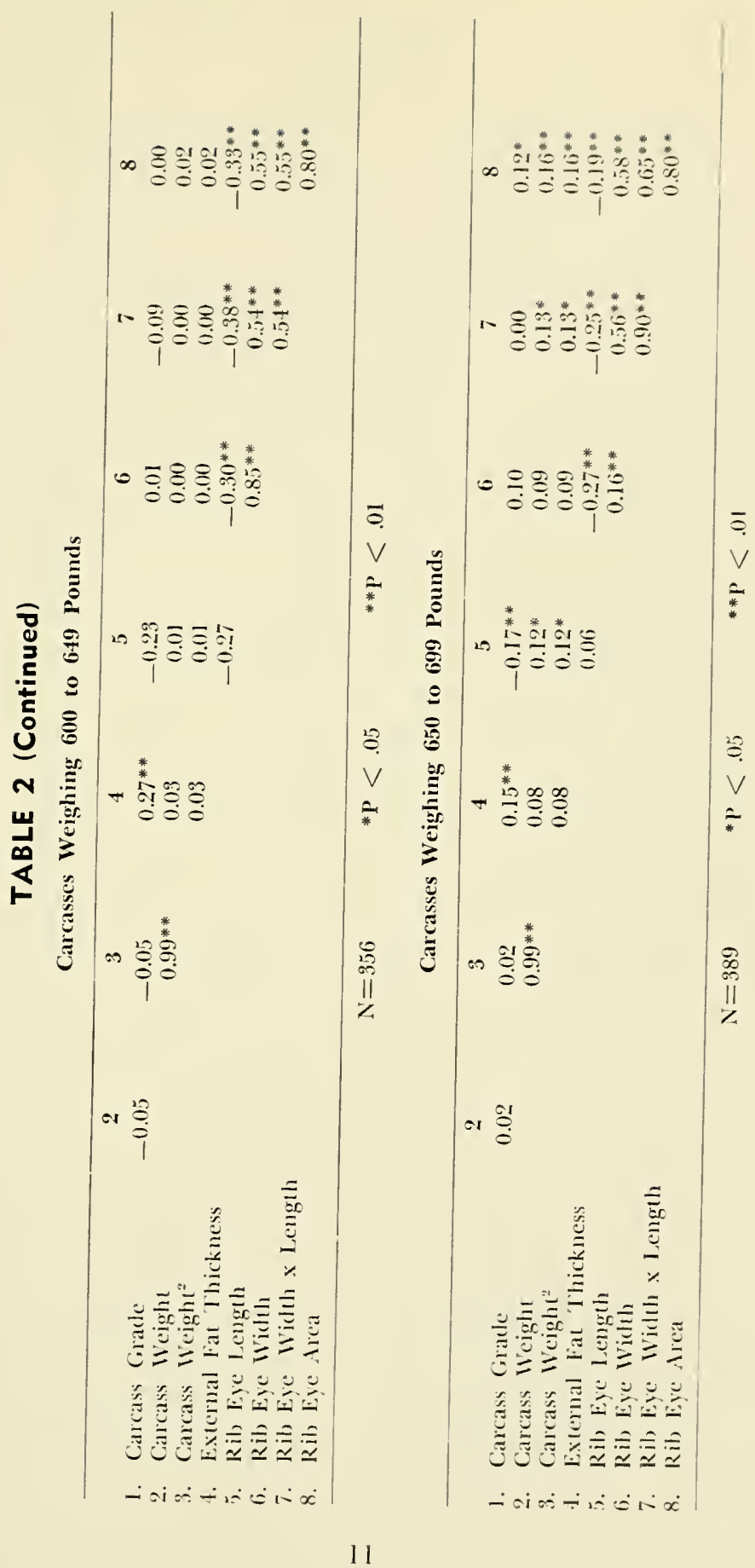




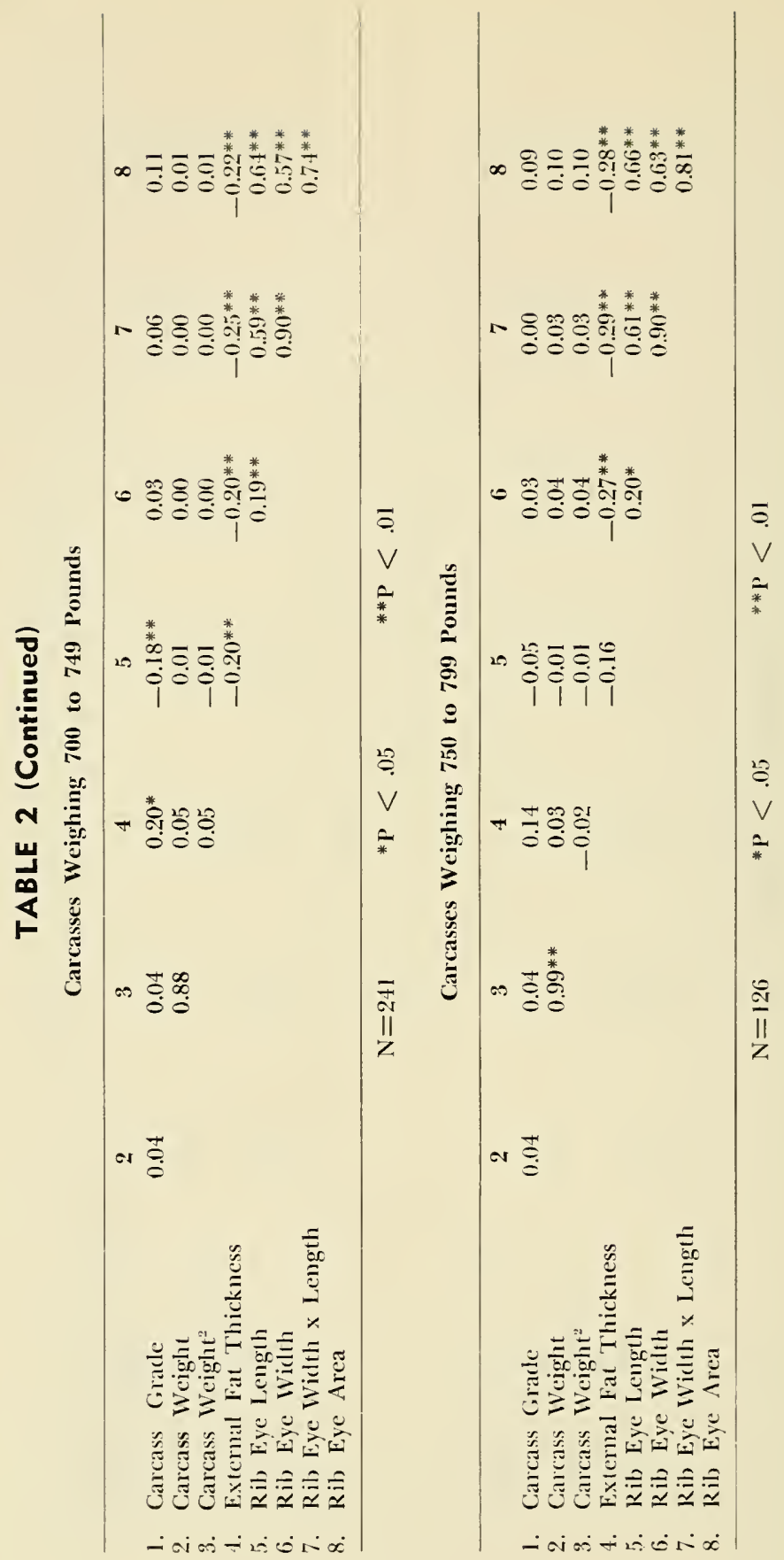




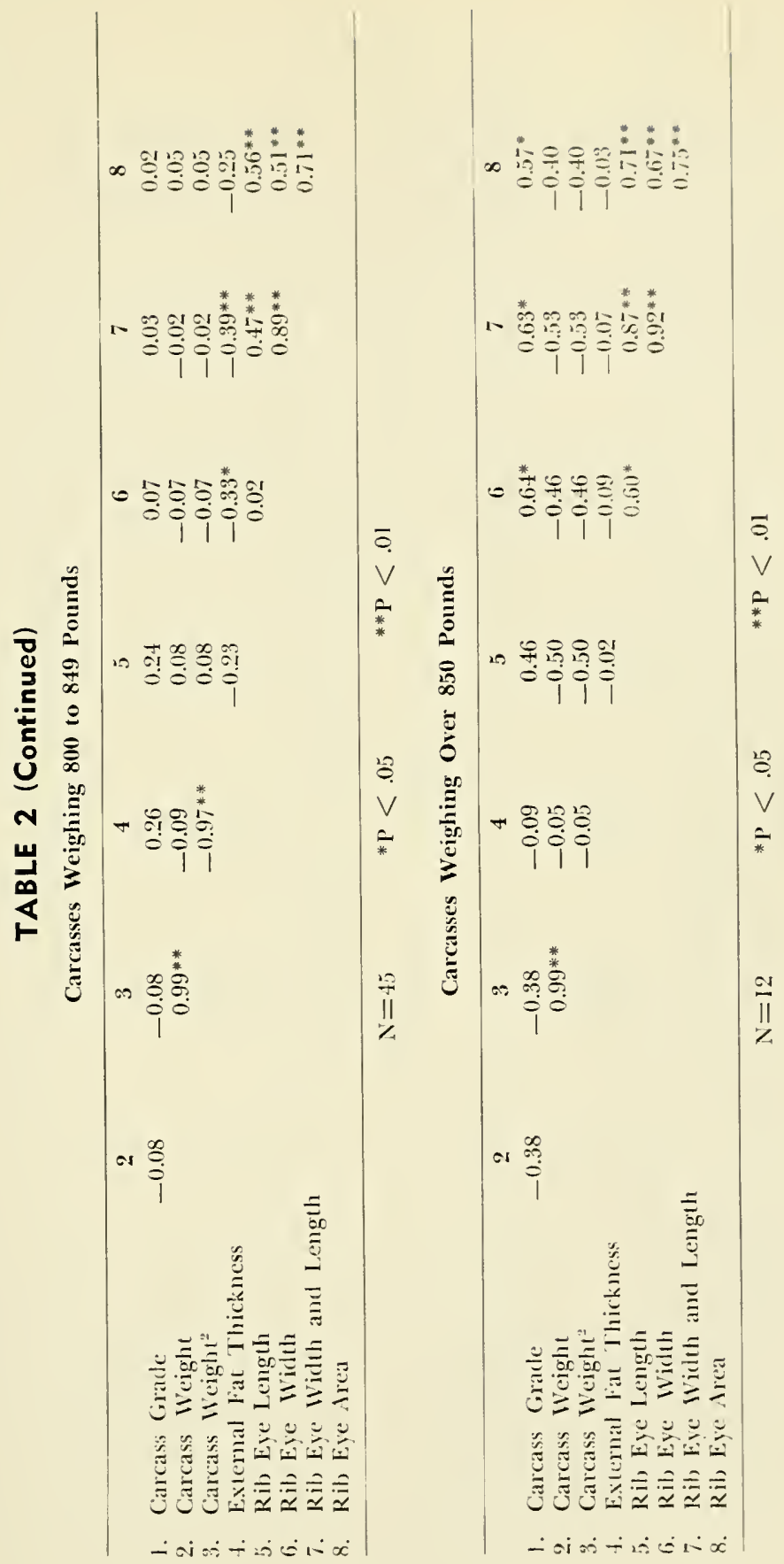




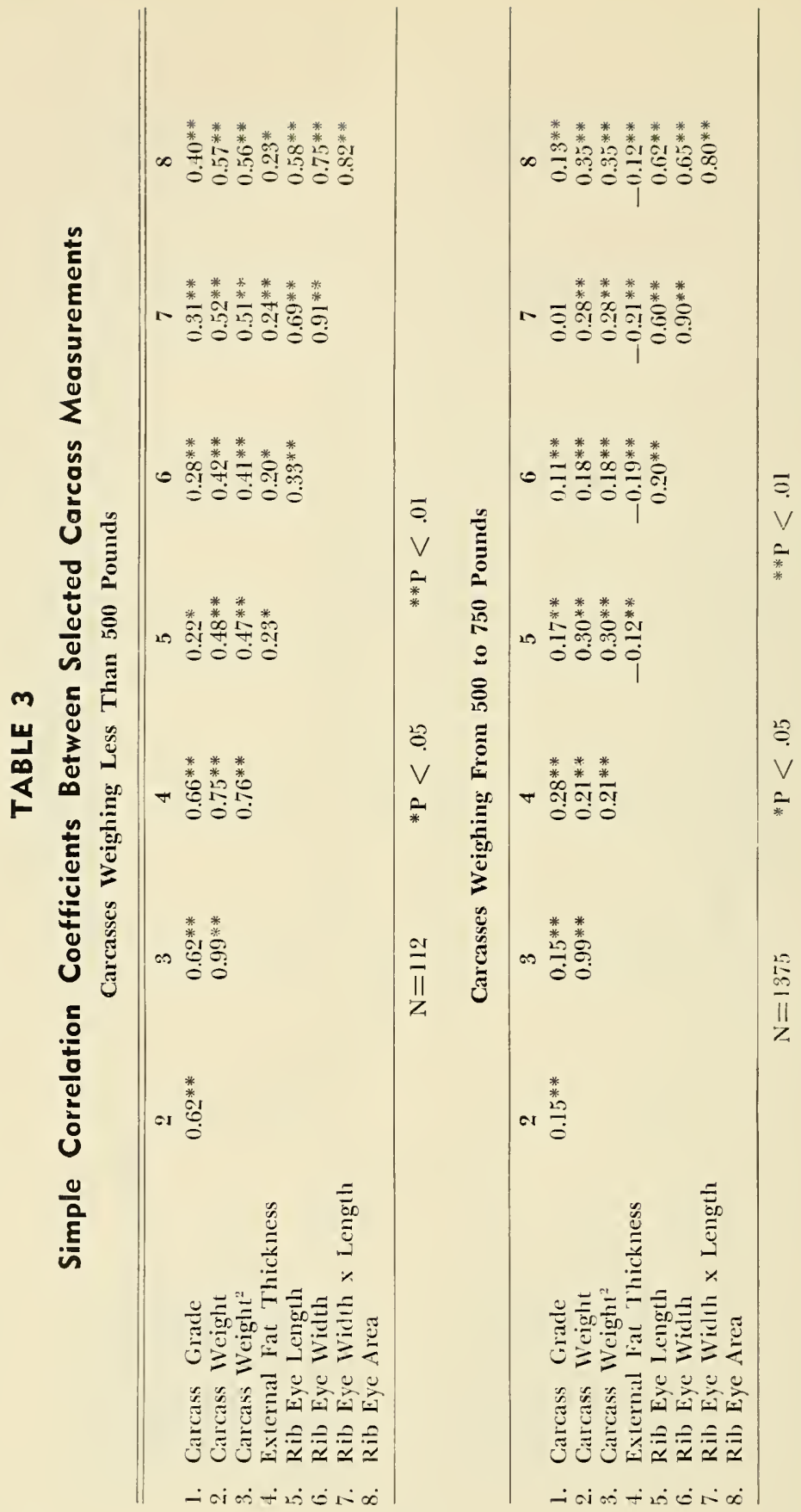



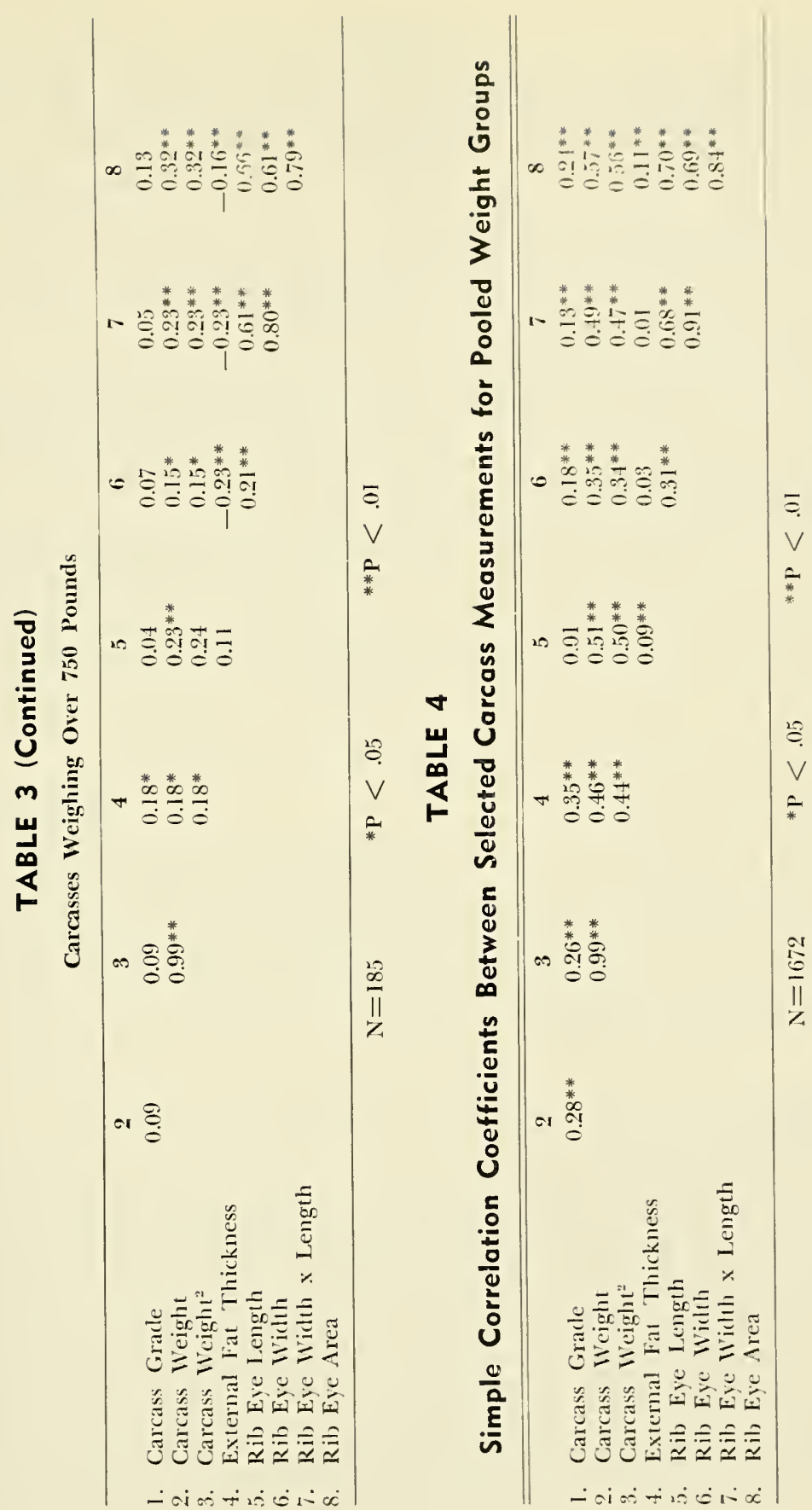


\section{TABLE 5}

Multiple Correlation Coefficients Between Rib Eye Area and Selected Carcass Measurements and Equations for Predicting Rib Area of Carcasses

\begin{tabular}{c}
\hline R \\
Calcasses weighing 250 to 950 pounds \\
0.57 \\
1.22
\end{tabular}

Carcasses weighing less than 500 pounds

$0.86 \quad 0.56$

Carcasses weighing 500 to $\mathbf{7 5 0}$ pounds
0.83
0.72

0.83

0.73

0.81

0.76

Carcasses weighing over 750 pounds
0.83
0.75

0.82

0.77
$Y=6.3089-0.1702$ (carcass grade) +0.0084 (carcass weight).

$\mathrm{Y}=7.2933-0.2612$ (carcass grade) +0.0047 (carcass weight) -0.5635 (fat thickness, cm.) +0.0716 (rib eye length $\mathrm{x}$ width, cm.).

$\mathrm{Y}=6.3999-0.3002$ (carcass grade) -0.0018 (carcass weight) +0.8006 (rib eye length, cm.) +0.9570 (rib eye width, cm.).

$\mathrm{Y}=5.8672-0.3313$ (carcass grade) +0.8103 (rib eye length, cm.) +0.9724 (rib eye width, cm.).

$\mathrm{Y}=6.1466+0.7890$ (rib eye length, cm.) +1.0180 (rib eye width, cm.).

$\mathrm{Y}=6.7022-0.2532$ (carcass grade) -1.0567 (rib eye width, cm.) +0.1376 (rib eve length $\mathrm{x}$ width, cm.).

$\mathrm{Y}=33.0232-1.0222$ (rib eye width, cm.) +0.1365 (rib eve length $\mathrm{x}$ width, cm.).

a Standard error of estimate.

\section{Summary}

Carcass weight, carcass grade, subcutaneous fat thickness and rib eye length, width and area measurements were obtained from 1,672 steer carcasses representing the four top grades and a wide weight range. These carcasses were partitioned into various weight groups and simple correlation coefficients were calculated between carcass traits. A multiple linear regression analysis was used to obtain regression coefficients for the carcass traits in this study.

Carcass grade was highly correlated with carcass weight, carcass weight ${ }^{2}$ and fat thickness in the lighter weight group. Correlations between carcass grade and weight, fat thickness and rib eye measurements 
declined as carcass weight increased. These results were attributed to the relative rate of muscle and fat deposition as carcass weight increased.

Carcass weight and weight ${ }^{2}$ were more highly correlated with rib eye measurements in carcasses weighing less than 500 pounds than orer 500 pounds. Muscling affecting weight in carcasses weighing less than 500 pounds more than did fat.

High correlations were obtained between fat thickness and carcass grade, weight and weight" for carcasses weighing less than 500 pounds. This resulted from fat being deposited more rapidly as the weight of the carcasses increased toward 500 pounds. Correlations between fat thickness and rib eye length were low and inconsistent in sign. Correlations between fat thickness and rib eye width, rib eye length $\mathrm{x}$ width and rib eye area indicated fat deposition increased as rib eye measurements increased in carcasses weighing less than 500 pounds. In carcasses weighing over 500 pounds, more fat was being deposited in proposition to the increase in rib eye measurements.

Rib eye length was not highly correlated with rib eye width, but length and width were both highly correlated with rib eye length $\mathrm{x}$ width and rib eye area.

\section{Bibliography}

Cahill, V. R., L. E. Kunkle, E. W. Klosterman, F. E. Deatherage and E. Wierbicke. 1956. "Effects of Diethylstibestrol Implantation on Carcass Composition and the Weight of Certain Endocrine Glands of Steers and Bulls." J. Animal Sci. 15:701.

Cole, J. W., C. B. Ramsey and R. H. Epley. 1962. "Simplified Methods for Predicting Pounds of Lean in Beef Carcasses." J. Animal Sci. 18:1485.

Hedrick. H. B., W. E. Meyer, M. A. Alexander, J. F. Lasley, J. E. Comfort, A. J. Dyer and H. D. Nammann. 1963. Indices of Meatiness in Beef. Mo. Igr. Exp. Sta. Res. Bul. 820 .

Hirzel, R. 1939. "Factors Affecting Qualizy in Mutton and Beef will Special Reference to the Proportions of Muscle, Fat and Bone." Onderstepoort. J. Veterinary Sci. 12:379.

Merkel. R. A. and D. L. Mackintosh. 1961. "Relationship of Muscle, Fat, lione and Some Physical Measurements of Beef Carcass Cutability:" J. Animal Sci. 20:917.

Miller, J. C., H. B. Hedrick, G. B. Thompson, R. R. Feitog, W. E. Mever, A. J. Dyer and H. D. Naumann. 1965. Factors Affecting Longissimus Dorsi and Subculaneous: Fat Measurements and Indices of Beef Carcass Cutoul. Mo. Igr. Exp. Sta. Res. Bul. 880 .

Nammann, H. D. 1951. "A Recommended Procedure for Mcasming and Grading Beef for Carcass Evaluation." Proc. Reciprocal Mcat Conf. 4:89.

Weslie, J. D., D. L. Good and I. . I. Holland. 1958. Relationship Among Live and Car. cass Characteristics of Slaughter Steers. Kan. Igr. Fxp. Sat. Circ. 358.

Wiles, J. A. 1966. The Effect of Carcass Characteristics on the Acceptability of Beef. M. S. Thesis. We:t Virginia University. 

. 


6

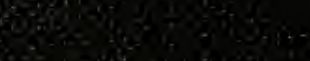

